\title{
A MULTI-CASE INVESTIGATION OF ENVIRONMENTAL LEGITIMATION IN ANNUAL REPORTS ${ }^{1}$
}

\author{
Arline Savage, A. J. Cataldo and Jeff Rowlands
}

\begin{abstract}
In this chapter, a legitimacy theory framework for corporate environmental disclosure is empirically investigated, using a multi-case research design. Legitimation strategies in the 1991 to 1995 annual reports of two Canadian-owned pulp and paper companies are explored. The findings support legitimacy theory as an explanation for voluntary environmental disclosure in annual reports.
\end{abstract}

\section{INTRODUCTION}

This chapter empirically investigates a legitimacy theory framework for voluntary environmental disclosure in annual reports. A multi-case research design is used to identify legitimation strategies in the annual reports of two Canadian-owned pulp and paper companies over a five-year period. The primary objective is to determine whether voluntary disclosures of environmental information in annual reports are strategic attempts to counter perceived extant or potential challenges of organizational legitimacy, arising from corporate activities impacting the natural environment.

Decision-usefulness and economic theories have been used in attempts to explain voluntary corporate social disclosure (CSD), but have generally proved 
restriclive and unsatisfactory (Gray et al., 1995a; Gray et al., 1987, 63-90, 1988; Mathews, 1993, 2-4, 1998; Preston, 1975; Puxty, 1986; Savage, 1998). Arnold (1990) posits that the field of CSD is devoid of any substantive, theoretical foundation, and Ullmann $(1985,555)$ describes CSD as "empirical data in search of an adequate theory." This chapter attempts to further develop and provide empirical support for an underlying theoretical framework.

A possible explanation for the increasing phenomenon of voluntary CSD is the corporate quest for organizational legitimacy (see Gray et al., 1995a; Hogner, 1982; Mathews, 1993, 217; Patten, 1991, 1992; Puxty, 1986; Richardson, 1987; Savage, 1998; Tinker \& Lowe, 1980). A state of legitimacy is attained when societal perceptions of corporate behavior are congruent with societal expectations of corporate [envirommental] activity (Dowling \& Pfeffer, 1975). To achieve this state, legitimation strategies are used in attempts to justify corporale coexistence with society.

Although one accounting study involving an Australian corporation failed to support a legitimacy theory framework (Guthrie \& Parker, 1989), at least seven studies have successfully used a conceptual definition of legitimacy theory to explain CSD in annual reports (Hogner, 1982; Guthrie \& Parker, 1990; Patcen, 1992; Deegan \& Gordon, 1996; Deegan \& Rankin, 1996, 1997; Buhr, 1998). None of these identify measures of legitimacy. There is no satisfactory alternative or competing theory to explain the phenomenon of voluntary CSD, although two complementary theories, stakeholder theory and political economy theory, have been identified (Gray et al., 1995a; Buhr, 1998).

An eighth study, conducted by Neu et al. (1998), examined 33 public companies over a ten-year period (1982 to 1991), operating in four 'environmentally-sensitive' industries. Six of these firms were in the pulp and paper industry. Their regression model used an environmental issues-based annual report word count as the dependent variable and examined its relation to seven independent variables. Three of the independent variables examined the frequencies of: (1) articles addressing environmentally-based fines (FINES), (2) general environmental criticisms (MEDIA), and (3) published Canadian newspaper and periodical articles (SOCIETY). The predicted signs of significant (at the $1 \%$ level) coefficients for these independent variables were either 'assumed' or not fully developed in the paper, and were also not consistent in direction.

The present study also focuses on FINES, MEDIA and SOCIETY variables, but does so on a different dimension, and is based on the assumption that the technology does not presently exist to perform quantitative analyses on legitimacy theory motivation for corporate environmental disclosure. Therefore, this explanatory study uses a structured case study approach to examine 
corporate environmental disclosure, which is the fastest growing form of CSD (Gray, 1993, 1994; Gray et al., 1993, 181, 1995a). Adverse media reports are used as an indirect measure of legitimacy (see Savage, 1998). The results are consistent with the hypothesis.

The next Section presents a synopsis of the theory. Section III describes the research design. Section IV presents the case evidence and Section V specifies the limitations. The final Section concludes the study.

\section{LEGITIMACY THEORY FRAMEWORK}

Savage (1998) provides an extensive literature review and an organizational legitimacy theory framework to explain corporate environmental disclosure from a social contract perspective. In terms of legitimacy theory, organizations attempt to establish congruence between the social values associated with or implied by their [environmental] activities, and the norms and values of the society of which they are part (Dowling \& Pfeffer, 1975). They do this by using legitimation strategies to justify their coexistence with the public-at-large and to continue their economic pursuits, which provides for their long-term survival. If this balance is even perceived to be disturbed, a legitimacy gap arises. But, legitimacy is difficult to measure.

Savage (1998) argues that news media reports are indicators of societal norms and values, and provides references for this position from the sociology, organizational theory, and accounting literature streams. Based on this, if a perceived threat to the larger collective social interest arises because of the actions of an organization, the legitimacy of the organization and/or its industry will be challenged in the news media, in the form of adverse news media reports. An adverse news media report is defined as one that reflects negatively on the environmental activities of the company. Once a legitimacy gap has been identified by one or more adverse media reports, and organizational legitimacy challenged, corporations would select one, or a combination, of legitimation strategies to close the existing or perceived legitimacy gap. The magnitude of a legitimacy gap would be reflected by the number of adverse media reports giving rise to the gap. Because the annual reports of public corporations are generally accepted as a channel of communication to interested members of society, they represent a logical (but not the sole) medium for legitimationrelated communications (for support of this position, see Deegan \& Rankin, 1997, 580; Flinn, 1995; Robertson \& Nicolson, 1996).

Environmental legitimation is therefore a dynamic, cyclical process of continuing societal appraisal of corporate environmental activities in terms of prevailing norms and values. If a legitimacy gap is perceived, adverse media 
reporting will follow. On perceiving a threat to organizational legitimacy, a corporation will invoke one or more strategies to close the gap. Communication to society will then take place, with the annual report as one medium. The next section describes the various legitimation strategies that a corporation may choose to employ.

\section{Legitimation Strategies}

The organizational theory literature identifies nine legitimation strategies. Consistent with the research method employed, three additional strategies were identified during the course of this study. The three new contributions to the accounting literature are not pre-specified, but are included in this section for completeness and ease of reference only. The 12 legitimation strategies may be classified into two broad categories of legitimation activity. These are:

(1) Substantive activity: ${ }^{2}$ This category involves real, material change to organizational goals, structures and processes, or in socially institutionalized practices. Society generally favors concrete, substantive responses (Ashforth \& Gibbs, 1990; Suchman, 1995).

(2) Symbolic activity. ${ }^{3}$ This category does not involve real changes, but attempts to portray corporate activities as compatible with societal norms and values (Ashforth \& Gibbs, 1990; Pfeffer, 1981, 28). Management generally favors symbolic assurances, since they are more economical and flexible than substantive actions.

The 12 strategies are classified and defined below. Ashforth \& Gibbs (1990) offer an in-depth discussion on the three substantive and first six symbolic strategies. The last three symbolic strategies emerged from the empirical work completed in this study.

\section{Substantive Strategies}

(1) Role performance: The most obvious attempt at legitimation is where the organization adapts its goals, methods of operation, and/or its output to conform to the performance expectations of the members of society on whom it depends for critical resources (Dowling \& Pfeffer, 1975). This strategy could be chosen in response to a legitimacy gap resulting from actual performance failure by the organization (Lindblom, cited by Gray et al., 1995a, 54), or where performance expectations are determined by market, normative, legal or political forces, and fulfilment of these expectations is essential for survival. 
(2) Coercive isomorphism: This is a more subtle, evolutionary legitimation process (DiMaggio \& Powell, 1983; Meyer \& Rowan, 1977). It is manifested by a blending, over time, of evolving societal norms and values into an organizational structure, signaling the willingness and ability of the organization to conform to society's collective values. The organization becomes substantively 'matched' with its cultural environment, by employing substantive strategies or by shifting from symbolic strategies to substantive strategies over time. This structurally legitimate organization becomes a repository of public confidence (Meyer \& Rowan, 1977; Suchman, 1995).

(3) Altering socially institutionalized practices: The organization could attempt, through communication, to alter the societal definition of legitimacy, so that the amended definition reflects the organization's activities. This is the most difficult strategy to successfully implement (Dowling \& Pfeffer, 1975).

\section{Symbolic Strategies}

(1) Espousing socially acceptable goals: The organization may advocate socially acceptable goals while pursuing less acceptable ones. It may, for example, disclose ethical policies, but fail to implement procedures to monitor compliance.

(2) Denial and concealment: The organization may simply deny or suppress information about activities that may undermine legitimacy.

(3) Identification with symbols, values or institutions: The organization could attempt to become identified with symbols, values or institutions with a strong, established base of social legitimacy (Dowling \& Pfeffer, 1975).

(4) Offering accounts: The organization may offer explanations, including excuses and justifications, designed to distance the organization from situations adversely affecting its legitimacy.

(5) Offering apologies: By apologizing, an organization may show some expression of remorse for a negative event.

(6) Ceremonial conformity: Certain highly visible and salient practices that are consistent with social expectations may be adopted, while leaving the formal structure of the organization intact. For example, scapegoating, or the formation of a task force to study the environmental impacts of activities, may provide the appearance of action without the substance (Pfeffer, 1981).

The next three strategies represent a new contribution to the framework, and resulted from the empirical component of this study. 
(7) Admission of guilt: By admitting guilt, an organization may acknowledge at least partial responsibility for a negative event, in an attempt to diffuse the situation by creating the impression and/or reality of honesty.

(8) Misrepresentation or open to misinterpretation: The organization may intentionally or unintentionally give a false impression or account, or supply ambiguous information that could be misleading or open to misinterpretation.

(9) Avoiding, trivializing or skirting around the issue: The organization may offer a partial explanation, trivialize or fail to directly address an issue. The information may not be clearly conveyed or may simply be implied.

\section{Hypothesis Development}

One of the primary motivations that the concept of organizational legitimacy has for management is communication with society. In this study, it is hypothesized that environmental disclosure in annual reports is part of the corporate legitimation process, which is indicative of the degree of 'fit' between societal expectations and organizational activities (Zenisek, 1979). We argue that, if an organization voluntarily discloses environmental information in its annual report, then this disclosure is a symbolic or substantive strategic attempt to counter perceived existing or potential challenges to its legitimacy, arising from corporate (industry-related and/or company-specific) activities affecting the natural environment. More specifically, and incorporating an indirect measure of legitimacy, the research hypothesis is:

If a company has an item of voluntary environmental disclosure in its annual report, then this is a legitimation strategy used to respond to recorded societal noms and values and/or legitimacy gap(s) arising from adverse news media reports targeting the company and/or the industry in which it operates.

If a company wishes to extend or maintain its legitimacy via its annual report, it will respond to societal norms and values only. If it wishes to defend its legitimacy, it will respond to actual legitimacy gap(s) or to a combination of societal norms and values and legitimacy gaps.

Before focusing on research that attempts to explain or predict the use of any specific legitimation strategy, it is essential to first provide empirical support for the hypothesis that corporate attempts at legitimation are indeed the underlying cause for voluntary environmental disclosure. That is the purpose of this study. 


\section{RESEARCH DESIGN}

This explanatory study examines the forces underlying voluntary environmental disclosure in annual reports. Yin's (1989) multi-case research design is used to investigate the hypothesis. His book has become a standard reference for case study research design (Colbert \& Spicer, 1995). Consistent with Colbert \& Spicer $(1995,430)$, we believe that Yin provides the clearest and most coherent and comprehensive approach to multi-case explanatory research.

The primary objective of Yin's approach is to provide analyrical elidence about the empirical validity of the underlying theory, by matching case evidence back to theory, and not to generalize from a sample to a larger population (Yin, 1989,21). The pre-specified theory is "used as a template with which to compare the empirical results of the case study" (Yin, 1989, 38). It needs to state the conditions under which a particular phenomenon [corporate environmental reporting] will generally be found [when an extant or possible future legitimacy gap is perceived] and the conditions when it is not likely to be found [ when no existing or possible future gap is perceived] (Yin, 1989, 54). This characteristic has a profound effect on the selection of the cases to be investigated, which are chosen specifically because they exhibit some identified general theoretical principle, and not by means of a sampling method that ensures no bias.

Following Yin (1989), the researcher seeks "to specify the necessary" conditions among a set of theoretically-significant elements," and is not satisfied with explanations for most of the variance in the data, but seeks to explain all the data. Deviant cases are used as opportunities to refine the analysis so that the relationships described "have been analytically induced from the data" (Silverman, 1989, 62-63). If the outcome of a case is not as predicted, the theory must be modified (Yin, 1989, 54). In this manner, theory development takes place. Consistent with this, the empirical findings in this study resulted in an extension to the theory, in the form of three new symbolic legitimation strategies. These were (1) admission of guilt, (2) misrepresentation or open to misinterpretation, and (3) avoiding, trivializing, or skirting around the issue.

\section{Selection of Cases and Documents}

Two of Canada's largest wood products companies were investigated over a five-year period (1991 to 1995). Additional cases would be helpful, but the researcher should avoid thinking in terms of the "small sample size of cases" 
Yin $(1989,38-39)$, as the intention is not to generalize from a sample to a larger population, but to provide analytical evidence about the empirical validity of the theory (Colbert \& Spicer, 1995).

Selection of Companies. Consistent with previous empirical findings on CSD practices and their relevance to legitimacy theory (Savage, 1998), two corporations were selected within the following parameters:

(1) Canadian-owned, with annual reports issued in Canada, to minimize the effects of differences in international societal norms and values.

(2) Publicly conspicuous, due to their size.

(3) In an industry where environmental impacts are central and pervasive features of organizational economic activity. Resource-based companies generally have a significant impact on the natural environment and have the greatest likelihood of receiving adverse news media coverage. Using companies from resource-based industries is consistent with prior environmental reporting research (Buhr, 1994, 85; Buhr \& Freedman, 1996).

Therefore, the selected companies were: (1) Canadian-owned and listed on the Toronto Stock Exchange, (2) the largest companies in their industry, based on 1994 operating revenue, and (3) resource-based. Two companies in Canada's pulp and paper industry were selected. They were MacMillan Bloedel Ltd (MB) and Domtar Inc. This resource-based industry was chosen because:

(1) It is widely recognised as having significant environmental problems (Adams, 1992; Foot, 1996; Freedman \& Jaggi, 1988; Wiseman, 1982).

(2) Internationally, this industry is the most prolific discloser of environmental information (Buhr, 1994, iv; Fekrat et al., 1996; Niskala \& Pretes, 1995; United Nations Economic and Social Council 1992).

(3) According to a report in the Winnipeg Free Press (June 6, 1993, p. A8), entitled 'Forestry industries top poll's watch-closely list', Canada's pulp and paper industry continues to hold the distinction of the industry that people want governments to keep the closest watch on. This is consistent with other 1991, 1992 and 1993 poll results.

(4) As Canada's largest industry, pulp and paper has long been the backbone of its economy. The industry's contribution to Canada's trade balance is larger than the combined contributions of the mining, petroleum, fisheries, and agriculture industries (Gordon, 1997; Orton, 1991; Rusk, 1992; Sherbanowski, 1991).

Selection of News Media Reports. English newspaper reports about the environmental actions of the companies for the 1991 to 1995 fiscal years were selected from the Canadian Business and Current Affairs (CBCA) database 
(1996). Articles or press releases not originated by employees of the selected companies were used, as the intention was to examine public legitimacy challenges, and not the companies' response to these challenges via the news media. The news report selection process was performed by a graduate research assistant, replicated by the principal researcher, and the results compared.

\section{Procedures for Data Collection and Analysis}

The general analytic strategy was the use of legitimacy theory to explain corporate environmental disclosure.

Data collection. The data collection technique was document analysis. Data for the 1991 to 1995 fiscal years consisted of: (1) environmental disclosure in the annual reports of the companies and in environmental reports referred to in the annual reports; (2) recorded Canadian environmental norms and values; and (3) events reported in the news media, which implied negative industry-related and company-specific environmental actions. The data collection proceeded as follows.

Step 1. For (1) MB, (2) Domtar and (3) the pulp and paper industry, separate chronological descriptive lists of adverse news media reports were prepared, using the CBCA database as a source of reference. The lists were used as a source for collecting copies of the actual reports. Copies of the reports were used to identify and summarize actual or perceived legitimacy gaps, over the five-year period. From the analysis of the content of 164 adverse media reports in which $\mathrm{MB}$ was mentioned by name as the perpetrator of damaging environmental acts, 63 legitimacy gaps were distilled. For Domtar, 44 adverse media reports gave rise to 34 legitimacy gaps. For the industry, 145 news reports resulted in 48 legitimacy gaps. (Appendix $C$ gives examples of some of the MB gaps).

Step 2. A listing of Canadian societal norms and values, as they related to protection of the natural environment, was prepared. These were documented by (1) polling experts (i.e. Gallop Poll), (2) the environmental literature, and (3) as evidenced by major government initiatives. ${ }^{4}$

Step 3. For each company, all environmental disclosures in the annual reports, and in separate environmental reports referred to in the annual reports, were identified, measured, and recorded, by fiscal year, using content analysis (see Buhr, 1994, 98-110; Gray et al., 1995a, 1995b). The categories listed in Appendix A were used. These were supplemented by subcategories to refine the analysis. The coding proceeded as follows: Annual reports were read in their entirety and each unique piece of information was coded by a graduate research assistant on a document by document basis. This process was 
conducted in accordance with specific coding guidelines, devised by Buhr (1994, 346-348), and adapted for this study. These guidelines appear in Appendix B. Completed worksheets distinguished between voluntary and mandatory disclosure, according to Canadian GAAP, so that mandatory disclosure could be excluded. The procedure was independently replicated by the principal researcher, and the results compared.

The purpose of this step was threefold. First, a common language of crosscase concepts was generated (Miles, 1979), providing the structure for cross-case comparisons. Second, it ensured that all voluntary environmental disclosure was examined in the context of legitimacy theory, as opposed to an examination of only the envirommental data that fit the theory. Third, the coding was independently replicated, and the completeness and reliability of the results were enhanced.

Step 4. Using the coding worksheets as a reference, each item of environmental disclosure was comprehensively described.

Data analysis: All items of voluntary environmental disclosure were matched with specific legitimation strategies. Three techniques were used for analysing the evidence:

(1) Pattern-matching: An empirical pattern is compared with a predicted pattern, following the theoretical propositions of the framework. In explanatory studies, the patterns may be related to the dependent [i.e. environmental disclosures in the form of legitimation strategies] and independent [i.e. recorded societal norms and values, adverse news media reports and legitimacy gaps | variables. If the patterns coincide, the internal validity of the study is strengthened (Yin, 1989, 108-109).

(2) Explanation-building: This is used primarily for explanatory case studies. The objective is to build a general explanation that fits each of the individual cases, even though the details of the individual cases may vary (Yin, 1989, 113-114).

(3) Time-series analysis: There are different types of time-series analyses (Yin, 1989, 115-120). The type called 'chronologies' best suits this study. The analytical objective is to compare the chronology with that predicted by some explanatory theory [i.e. legitimacy theory], where the theory has specified that some events must always occur before other events [i.e. an extant or perceived legitimacy gap must occur before environmental disclosure takes place], with the reverse sequence not being an option.

Consistent with the analytical technicues, the operational procedure for the data analysis of each company was to 'pattern-match' the content of each item of envirommental disclosure with the content of adverse media reports 
preceding issuance of the annual report. From this detailed analysis, specific legitimation strategies could be identified. (Appendix $C$ gives examples from the $\mathrm{MB}$ case.) If all environmental disclosure could be pattern-matched to a legitimation strategy in this manner, the hypothesis would be supported.

The initial case was $\mathrm{MB}$. The findings were compared against the hypothesis, using the explanation-building technique. Consistent with the research methodology, the second case was analysed independently. Then, a cross-case comparison was conducted, which was the final stage of the replication process. The objective was to draw cross-case conclusions from the results of the individual cases. However, this manner of presentation resulted in a lengthy, repetitious discussion of results. Thus, consistent with the approach adopted by Colbert \& Spicer (1995, 443-444), the evidence and findings for both cases have been presented in a single section.

\section{Reliability and Validity}

There are two reliability issues: reliability in the collection of the documents (i.e. annual reports, news media reports and government publications), and reliability in the analysis of each document (recall that the data collection technique is document analysis). The extraction of the media reports from the database was done by the graduate research assistant, and replicated by the principal researcher. The government reports presented no problem as they were available upon request. No reliability problems were encountered in Steps $I$ and 3 of the data collection procedures, as the lists of events and the summary of Canadian performance expectations, norms and values were purely descriptive. This was merely a recording procedure, devoid of subjective decision-making and researcher bias.

For analyzing each annual report, the disclosure categories (Appendix A) were used in a standardized manner, so that any researcher would categorize (code) the data in the same way (Silverman, 1993, 147-148). The coding was done independently by two people, and the results compared.

Also, an evidentiary base was maintained, so that the supporting documentation leading to the case conclusions (annual reports, database primtouts, media reports, government reports, coding worksheets, detailed analyses) would be available for inspection. To further increase reliability, specific documents were cited in the working papers, so that the evidentiary base, upon inspection, would reveal the evidence (Yin, 1989, 98-103).

Construct, internal and external validity issues were also addressed. Construct validity was achieved by following specified data collection procedures, preparing worksheets detailing the results of the data collection 
and analysis, and cross-referencing (i.e. Yin's chain of evidence). Internal validity was addressed by using pattern-matching, explanation-building, and time-series analysis techniques. External validity is implicit in the multi-case study method, where replication logic is used.

Table 1 summarizes the stages of data collection and data analysis, and shows how the reliability and validity issues were addressed.

\title{
CASE EVIDENCE AND FINDINGS
}

\author{
Description of Cases
}

MB, Canada's largest pulp and paper products company, with 12886 employees, sales in excess of $\$ 5$ billion, and total operating assets of $\$ 4.6$

Table I. Reliability and Validity of Data Collection and Analysis

For Data Collection:

Collect adverse news media reports. Prepare a chronological, descriptive list for the industry and each case.

From media reports, identify and list company-specific and industry-specific legitimacy gaps.

Cattegorize norms and values.

Categorize disclosure on coding worksheet. Measure and describe.
Replicate and compare results; documentary database.

Cross-reference to media reports.

Maintain evidentiary database.

Replicate and compare results.

Cross-referencing;

Documents cited;

Evidentiary database;

Pattern-matching:

Explanation-building;

Time-series analysis;

Replication logic.

and/or

(2) legitimacy gap(s) (an independent variable). 
billion for the 1995 fiscal year, managed two million hectares of productive timberlands, approximately half of which were in British Columbia. MB is listed on NASDAQ and the Toronto, Montreal and Vancouver stock exchanges (MB Annual Report, 1995; MB Annual Statutory Report, 1991).

Domtar, a major North American manufacturer of pulp, paper, packaging, and lumber, with facilities situated throughout Canada and the U.S., ranks first among lumber producers in Eastern Canada, with 9503 employees, annual sales of $\$ 2.8$ billion and total assets of $\$ 3.2$ billion for the 1995 financial year. Domtar is listed on the Montreal, Toronto and Vancouver stock exchanges (1994 and 1995 Annual Reports).

\section{Test of Hypothesis}

Detailed, descriptive analyses of the environmental disclosures contained in the 1991 to 1995 annual reports of both $\mathrm{MB}$ and Domtar demonstrate that the findings were consistent with the hypothesis for each individual item of environmental disclosure. Each item of disclosure in the annual reports of each company was matched with categories of norms and values and/or legitimacy gaps, and the resultant legitimation strategies were identified.

\section{Major legitimacy problems}

MacMillan Bloedel. Throughout the five-year period, MB experienced attacks on its legitimacy. For 1993 through 1995, it received more direct adverse news coverage than the industry (in terms of number of industry-related adverse news reports - see Table 2), despite the industry's reputation as the worst environmental offender in Canada.

MB's adverse media reports resulted in the identification of 63 companyspecific legitimacy gaps over the five-year period, versus 48 industry-related

Table 2. Number of Adverse Media Reports

\begin{tabular}{lccc}
\hline Fiscal Year & MB & Domtar & Industry \\
\hline 1991 & 17 & 27 & 32 \\
1992 & 20 & 10 & 40 \\
1993 & 50 & 3 & 36 \\
1994 & 41 & 2 & 27 \\
1995 & 36 & 2 & 10 \\
Total: & 164 & 44 & 145 \\
\hline
\end{tabular}


gaps. MB's main legitimacy problems, derived from the content of adverse media reports, were:

(1) The decline of its public image and its perceived lack of concern for the environment (criticism - measured in terms of number of adverse reports - peaked in 1993);

(2) A large number of criminal convictions for illegal environmental activities (criticism began in 1993 and peaked in 1995);

(3) Its destructive, unsustainable forestry practices in British Columbia (criticism peaked in 1993), and the resultant damage to salmon and other marine life habitats (with criticism at its worst in 1993/94);

(4) Its unwillingness to change environmentally unfriendly processes and practices (criticism peaked in 1993);

(5) Its association with the Clayoquot Sound controversy. Public protests against MB's logging activities, in one of the world's largest remaining tracks of temperate rainforest, resulted in 932 arrests. This was the largest act of civil disobedience in Canadian history, resulting in the largest mass trial in the history of the western world. Protesters were charged with criminal contempt of court for defying a $\mathrm{MB}$-induced injunction banning demonstrations on company work sites. The resulting media reports represented the most severe attack on MB's legitimacy. They claimed that $\mathrm{MB}$ was responsible for harassment and attempted intimidation of protesters. Over 10,000 supporters visited the protesters' camp (MacIsaac \& Champagne, 1994). MB suffered severe and damaging public criticism, especially in 1993;

(6) The Clayoquor Sound events led to boycotts and threats of boycotts of MB products, which could adversely and materially affect the company's financial condition, earnings, liquidity and even its survival (attacks peaked during 1994/95); and

(7) A major chlorine dioxide spill at MB's Powell River plant in 1994 caused extensive, deadly air and water pollution (criticism peaked in 1994).

Primarily as a result of (5) and (6) above, MB appeared to be in the throes of a major legitimacy crisis; the industry was in the same position. As the clominant firm in the industry, $\mathrm{MB}$ contributed to this negative public perception in a profound manner. Media criticism of the industry and MB frequently appeared in the same report. Major industry legitimacy gaps were:

(1) Water and air pollution, caused by pulp mill effluent, poisoning fish and endangering human health. Pulp mills were accused of discharging highly toxic dioxins and furans, from their chlorine-bleaching process, into the 
environment. Markets began demanding chlorine-free products (criticism peaked during 1991/92);

(2) A deterioration of reputation due to a perceived lack of concern for the environment (criticism peaked in 1991, but remained strong through 1993);

(3) An unwillingness to change environmentally unfriendly processes and practices, especially at pulp mills (criticism peaked in 1992);

(4) Destructive, unsustainable practices, especially relating to lorest management in British Columbia (criticism peaked in 1993). Poor logging and clear-cutting practices destroyed forest ecosystems and damaged salmon, other marine life, bird and wildlife habitats (criticism peaked in 1993);

(5) The threat of an international boycott of Canadian forest products in retaliation for the industry's destructive logging practices (criticism was most pronounced in 1994).

Domitar: Domlar's worst year was 1991, with 27 'bad news' reports (see Table 2). Most of these related to land contamination at old plant sites. There was a significant decline, to 10 reports, in 1992; a further decline to three for 1993; and for 1994 and 1995, adverse company-specific media reports stabilized at only two reports respectively. The number of industry-related reports far exceeded those targeting Domtar directly. Therefore, the inclustry was experiencing more of a legitimacy problem than Domtar. Domtar-specific "bad news' reports resulted in the identification of 34 legitimacy gaps, vs. 48 industry gaps. Domtar's main problems were:

(1) Toxic land contamination left behind at a number of its old woodpreserving plants, and its apparent inability to restore these sites (the subject of 26 of the 34 Domtar legitimacy gaps, with 21 originating in 1991); and

(2) Air and water pollution caused by its pulp mills (six gaps, from 1991, 1993 and 1994).

Cross-case comparison. Domtar's major concern was its inability to remedy toxic land contamination, despite government clean-up orders and threats of legal action. Attacks on its legitimacy, though bitter, originated from the communities in which the old plants were situated, and from government demands for remediation. The site contamination damaged the company's reputation, but did not provoke international condemnation, unlike the $M B$ Clayoquot Sound controversy. A more serious threat to Domtar was the call for an international boycott of Canadian forest products, due to the industry's destructive logging practices. Domtar itself was not the subject of adverse media reporting in this regard. 
Generally, MB's legitimacy problems were far more serious than Domtar's, based on the number of adverse news reports, and widespread condemnation of MB's environmental actions. In particular, $M B$ experienced a self-inflicted legitimacy 'crisis' (Clayoquot Sound), as opposed to Domtar's self-inflicted legitimacy 'problem' (site contamination). In contrast to MB, Domtar's serious legitimacy concern, i.e. the call for an international boycout of Canadian forest products, was industry-imposed. The difference in intensity between these threats will be used to explain some of the variations in the results of this study. In this regard, Laughlin (1991) would argue that MB was subjected to much larger exogenous shocks than Domtar.

Another difference was that MB's main legitimacy threat was not subject to mandatory GAAP disclosure requirements, while Domtar's was. Canadian GAAP requires that future site restoration costs be recognized as a liability in financial statements.

Both companies addressed all major legitimacy gaps (company-specific and industry-related) in their annual reports.

\section{Patterns of Media Reports and Disclosures}

MacMillan Bloedel (Fig. 1). Adverse reports, specifically targeting MB, increased in 1992, peaked in 1993, and declined for both 1994 and 1995. Adverse industry reports followed a similar pattern, but with a one-year preemptive lag. For the post-1991 period, a pattern emerges.

MB reacted sharply in its annual reports, especially from 1993 through 1995, when the number of $\mathrm{MB}$-specific adverse media reports exceeded those for the industry. MB also introduced its first separate environmental report in 1993 and devoted a significant amount of space to environmental disclosure, escalating $719 \%$ from 1992 (2.29 pages) to 1993 (18.76 pages). In 1994, both MBspecific adverse media reports and disclosure started to decline. This trend continued through 1995.

Legitimacy theory provides an explanation for these trends. The more direct the adverse public reaction to its environmental activities, the more $\mathrm{MB}$ attempted to defend its extant legitimacy, in a reactive response to its legitimacy crisis. The industry-related criticism was less direct and less urgent, hence the time lag in MB's response to industry-related gaps. Figure 1 suggests that the quantity of MB's disclosure was positively related to the number of adverse media reports, for both company-specific and industry-related reports.

Domtar (Fig. 2). The Domtar chart presents a very different fact pattern. Industry-related criticism exceeded company-specific criticism throughout the 
five-year period. The latter peaked in 1992, whereas adverse media reports targeting Domtar peaked in 1991, and then declined each year until 1994/95, when the number stabilized at only two adverse reports per year.

Domtar's lowest level of disclosure was in 1991, the year in which the number of company-specific media reports, dealing primarily with site contamination, was the highest. Mandatory GAAP disclosure resulted from this site contamination matter. Domtar's highest level of disclosure was in 1995, the year in which the quantity of both industry-related and company-specilic reports were lowest. For Domtar, no discernible pattern was observed between disclosure and adverse media reports.

Cross-case comparison. MB, in the throes of a legitimacy crisis. reacted far more intensely than Domtar to the number of adverse media reports, by increasing the quantity of its environmental disclosure substantially, and then

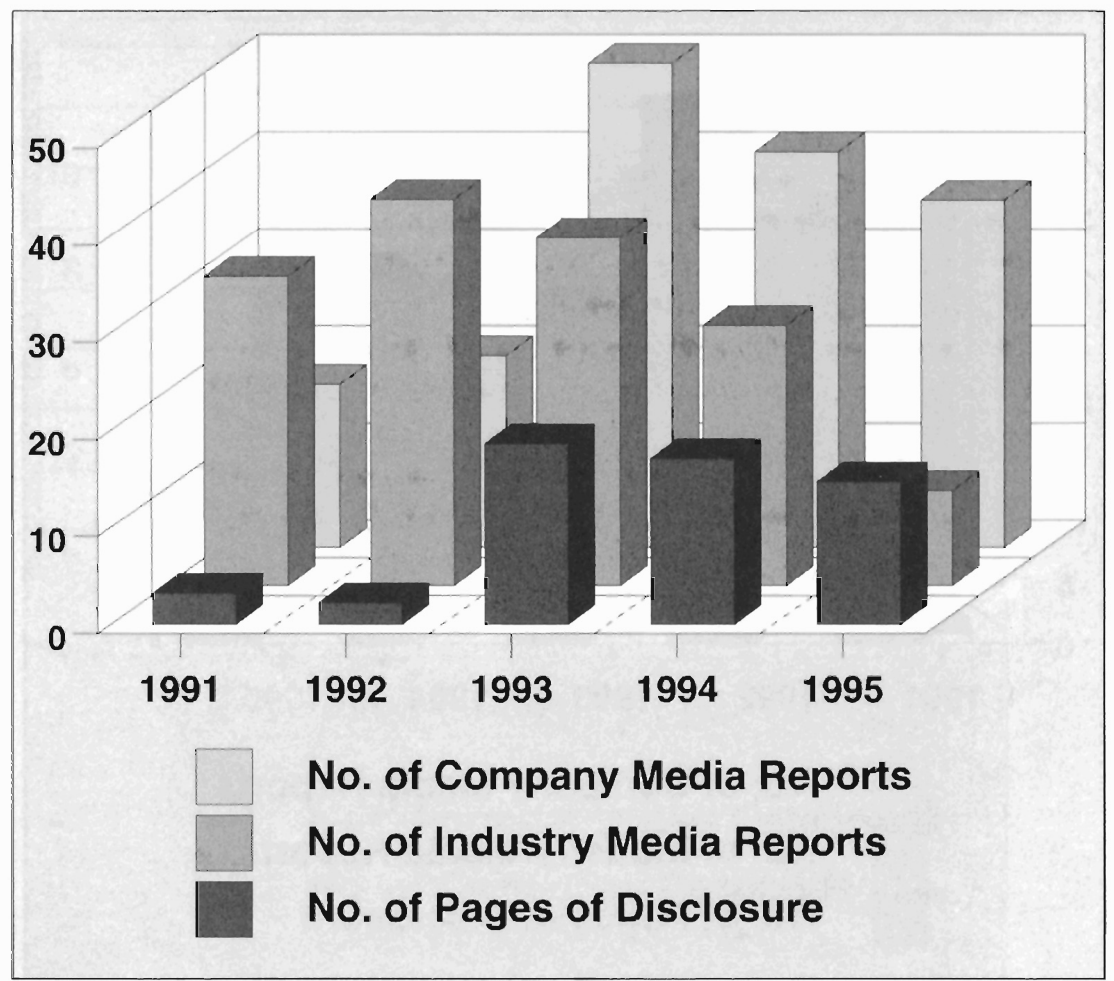

Fig. I. MB: Patterns of Reports and Disclosures. 
decreasing it slowly as the fuss waned. When comparing their worst years (1993 for MB vs. 1991 for Domtar), MB received 85\% more adverse press coverage than Domtar.

In its voluntary disclosure, $\mathrm{MB}$ reacted to its own problems, which overlapped with, and even exceeded, the major industry-related legitimacy problems. For Domtar, industry-related media attacks exceeded companyspecific attacks throughout the period. Its responses were directed toward these industry-related attacks. Its voluntary environmental disclosure does not appear to be positively related to company-specific adverse media reports.

Industry legitimacy problems were imposed on individual companies. For example, threats of an international boycott of all Canadian forest products because of perceived unsustainable industry logging practices affected Domtar. This explains Domtar's focus on industry-related problems in its disclosure.

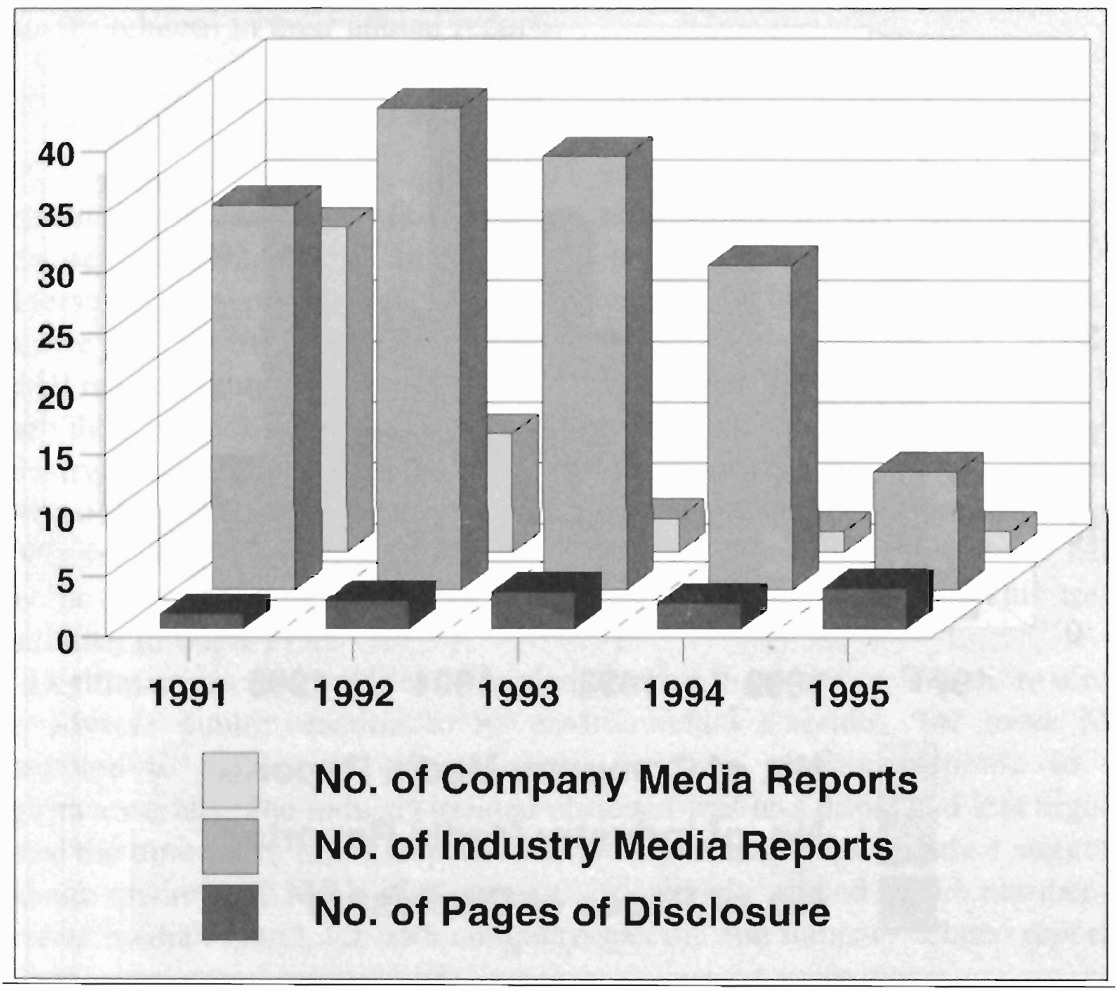

Fig. 2. Domtar: Patterns of Reports and Disclosures. 
MacMillan Bloedel (Fig. 3). MB moved progressively toward responding (1) an increasing number of categories of societal norms and values. As Fir. 3 suggests, MB was 'coerced' by societal demands and expectations into becoming more isomorphic over time.

Domtar (Fig. 4). Domtar was more uniform (1992 through 1995) in its response to societal norms and values, thus requiring less societal coercion toward an increased state of isomorphism. All categories of disclosure not responded to related to the company's biggest legitmacy problem. wood preservative effluents and contaminated sites.

Further investigation revealed that site restoration issues were dealt with in the mandatory sections of the annual reports, as required by Canadian GAAP.

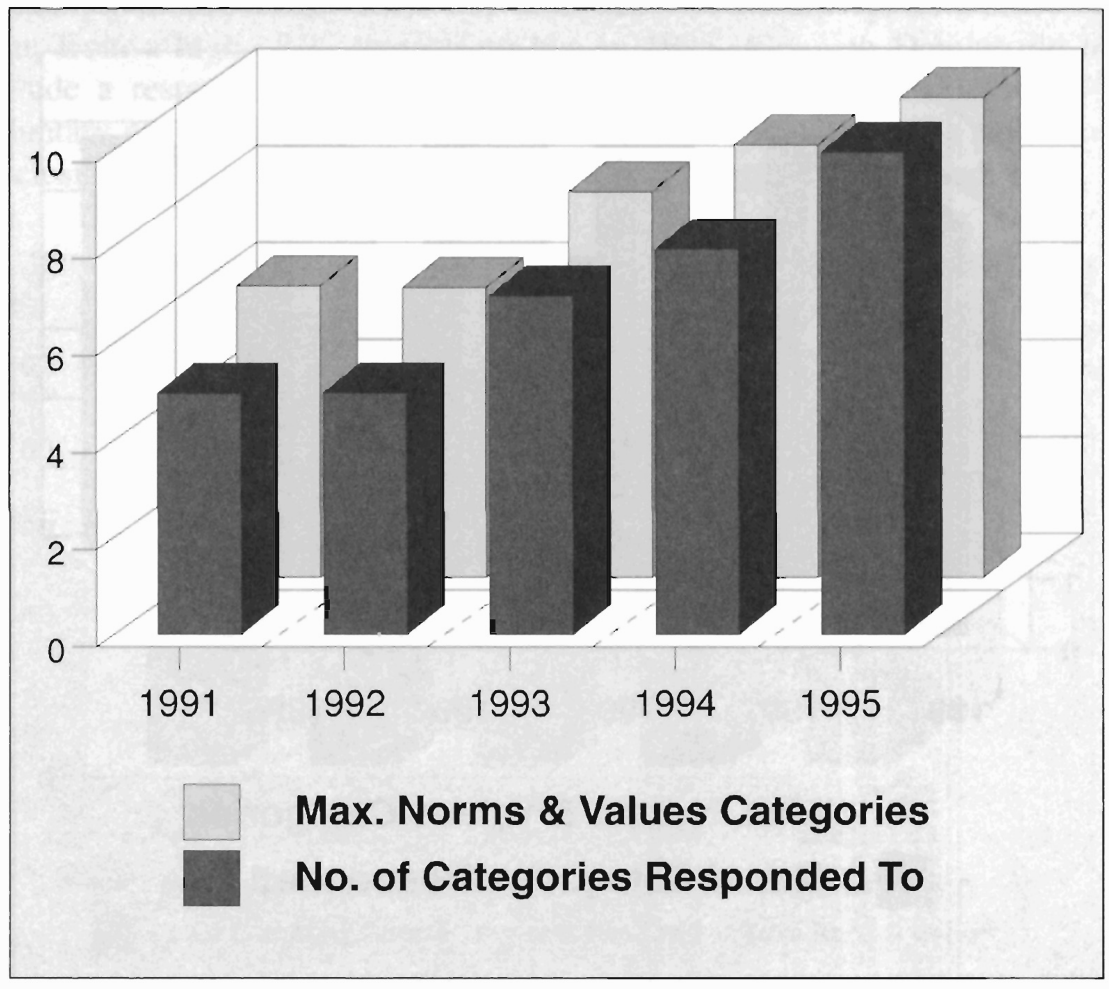

Fig. 3. MB: Keactions to Norms and Values. 
Therefore, this issue was not ignored by Domtar. Mandatory disclosure is beyond the scope of this study, as the purpose is to explain voluntary environmental disclosure. But, for comparability purposes, the calculations of response rates were amended to include this mandatory disclosure. The 1993 response rate rose from $71 \%$ to $86 \%$, and 1994 and 1995 rates both rose from $83 \%$ to $100 \%$. Overall, Domtar responded to the majority of the norms and values categories on a consistent basis over time, suggesting a high level of isomorphism.

Cross-case comparison. $\mathrm{MB}$ progressed toward an improved response rate during the five-year period. Domtar was generally more consistent in its response to societal norms and values throughout the period, with a better overall response to categories of norms and values.

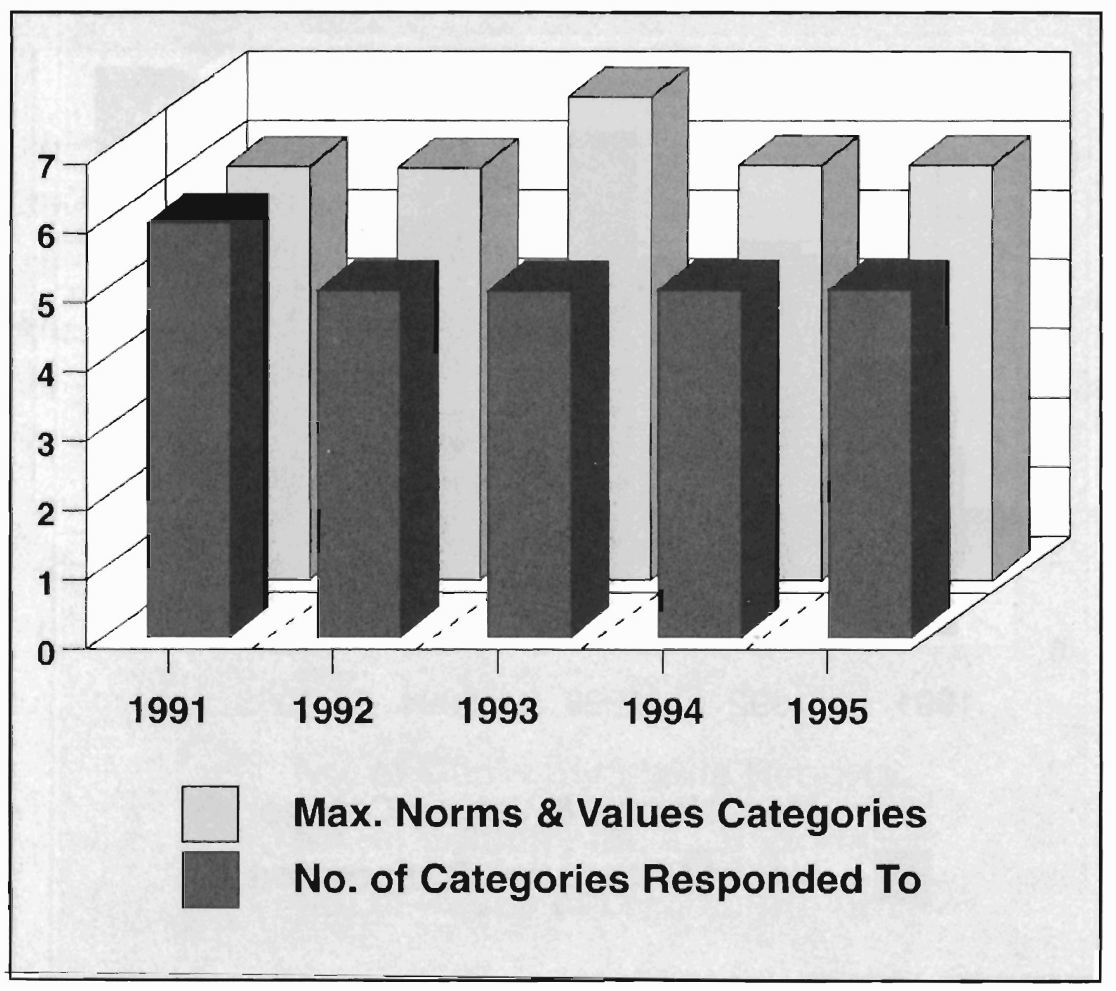

Fig. 4. Domtar: Reactions to Norms and Values. 
MacMillan Bloedel (Fig. 5). The results support the prevalence of the annual report as a corporate communications vehicle. Annual reports were extensively used to respond to adverse media reports for both industry-related and company-specific issues. This was particularly true for 1993, when the response rate was $97 \%$ to industry reports and 100\% to company-specific reports. On average, $\mathrm{MB}$ responded to $88 \%$ of the adverse media reports over the five-year period.

Domtar (Fig. 6). This chart also provides evidence of prevalent use of the annual report for corporate communications. For Domtar, the percentage response rate was particularly high for industry-related news reports, with an average response rate of $90 \%$. For company-related reports, the average response rate was $75 \%$. The rates for Domtar's worst year, 1991, were $81 \%$ and $74 \%$, respectively. The number of company-specific reports dwindled each year, from a high of 27 in 1991 to two in 1995. Although Domtar did not include a response to the two company-specific media reports in its 1995 voluntary environmental disclosure, the issue was addressed in its mandatory disclosure. Industry-related reports also decreased from 1993 through 1995.

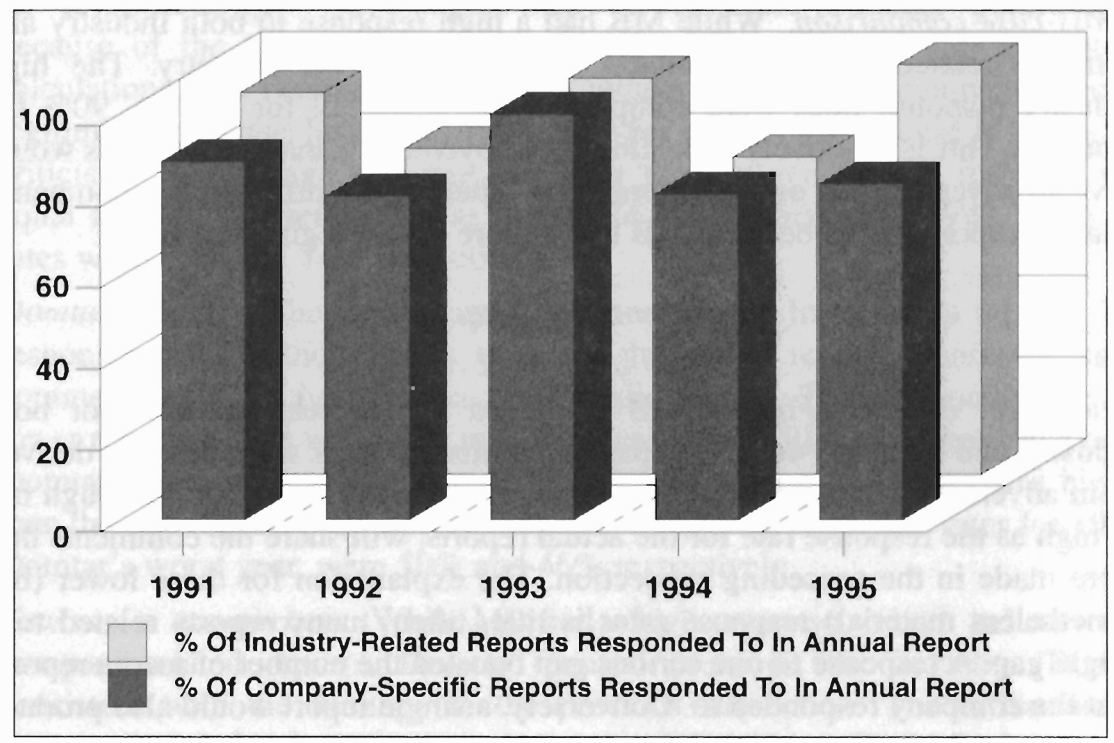

Fig. 5. MB: Response to Current Year Adverse Media Reports. 


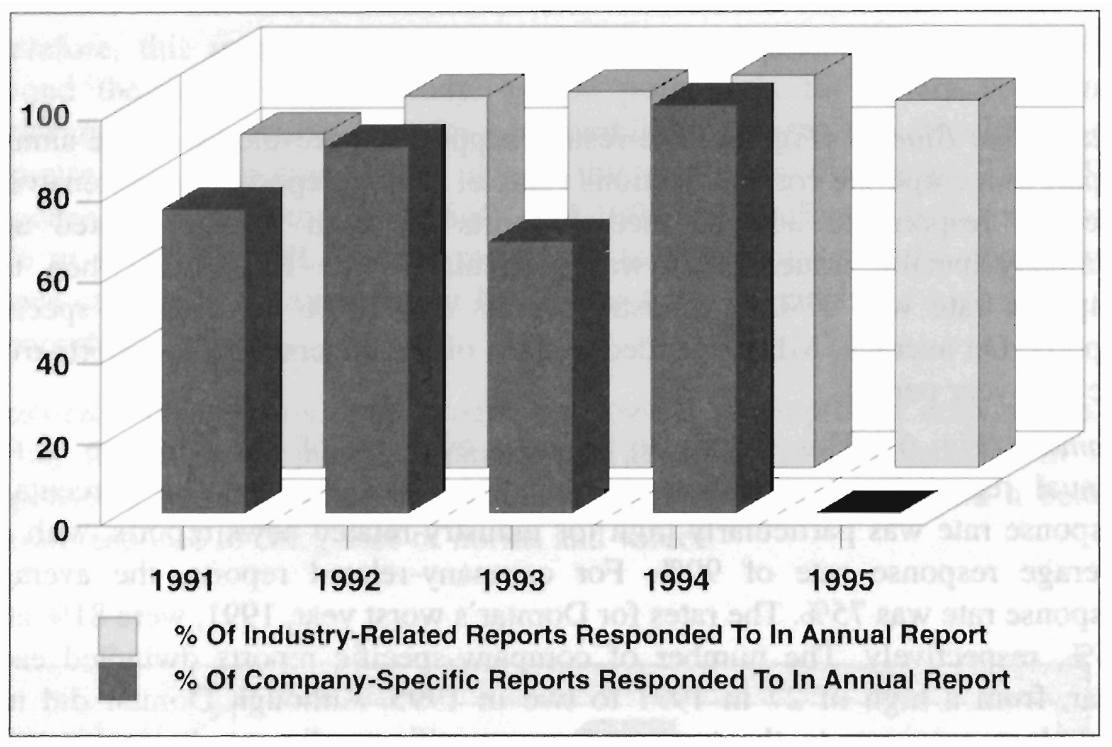

Fig. 6. Domtar: Response to Current Year Adverse Media Reports.

Cross-case comparison. While $\mathrm{MB}$ had a high response to both industry and company-related reports, Domtar's focus was on the industry. The high industry response rates were comparable $(88 \%$ overall for $\mathrm{MB}$ vs. $90 \%$ for Domtar). This is intuitively appealing, as a boycotl of Canadian products would have an adverse effect on both companies. There was a difference in companyrelated response rates because $\mathrm{MB}$ had a more severe legitimacy issue.

\section{Response to legitimacy gaps}

MacMillan Bloedel (Fig. 7). MB displayed a high response rate for both industry and company-related gaps. As legitimacy gaps were directly derived from adverse media reports, the response rate to legitimacy gaps, although not as high as the response rate for the actual reports, will share the comments that were made in the preceding subsection. The explanation for these lower (but nonetheless material) response rates is that, often, many reports related to a single gap. A response to one serious gap boosted the number of media reports that the company responded to. Conversely, a single report would also produce a gap. to which the company may not have responded because it was not considered threatenıng. Non-response to this type of gap had more of an impact 


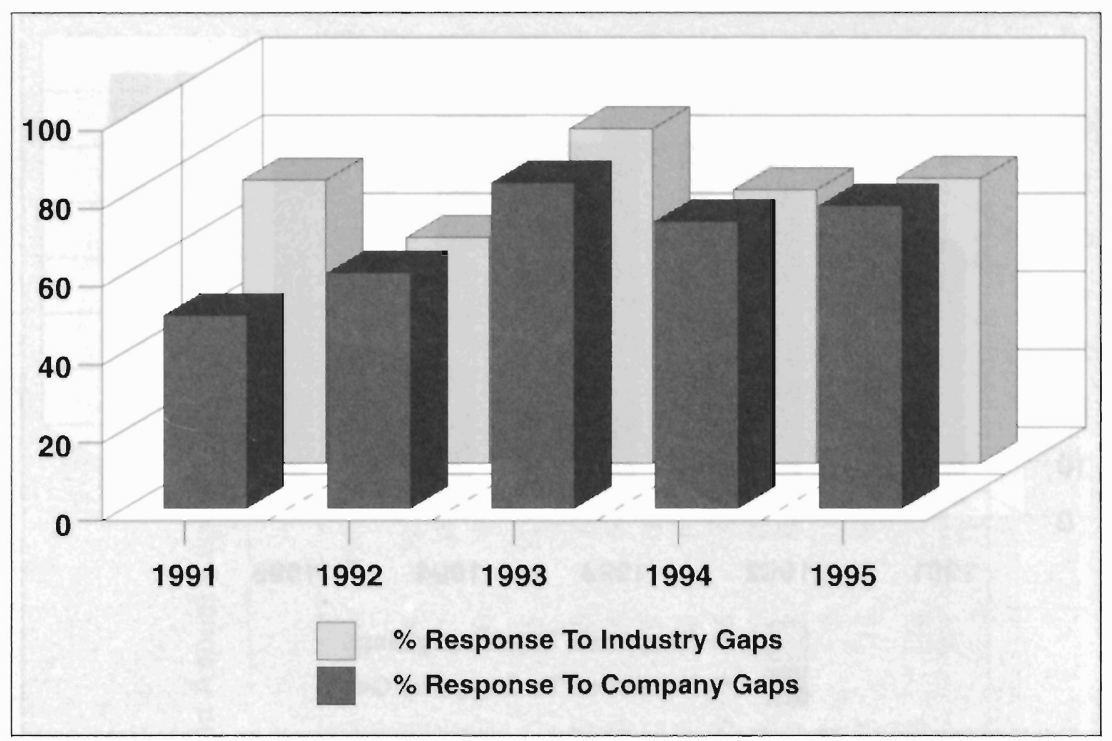

Fïg. 7. MB: Response to I egitimacy (iaps.

on response-to-gap percentages than on response-to-media percentages, because of the lower denominator used in the response-to-gap percentage calculations. The response rate to both industry-related and company-specilic legitimacy gaps was highest in 1993, the year of the most intense MB-specific criticism. The average response rate over the live-year period for each was equal at $73 \%$. The response was highest in MB's worst year, 1993, when the rates were $86 \%$ and $84 \%$ respectively.

Domtar (Fig. 8). The legitimacy gaps were derived from media reports. The responses rates, although less than for the actual reports, share the same comments as the subsection on news media reports. The explanation for the lower response rates was given in the MB case, and will not be duplicated here. Domtar's average response rate of $58 \%$ for industry-related gaps was higher than the rate for company-specitic reports, which was $41 \%$. The rates for 1991 , Domtar's worst ycar, were $50 \%$ and $46 \%$ respectively.

Cross-case comparison. While $\mathrm{MB}$ had a high response to both industry and company-related reports, Domtar focused more on the industry. This is consistent with the findings in the previous subsection. The difference in company-related response rates was because $\mathrm{MB}$ had a more severc legitimacy problem than Domtar. 


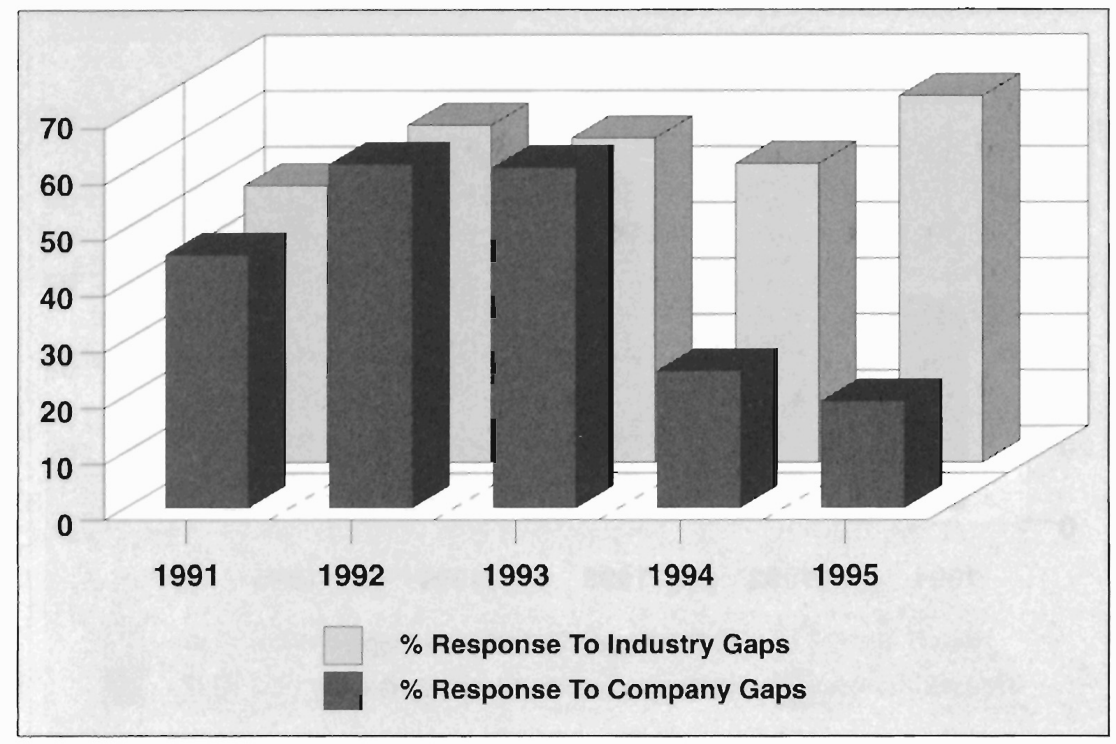

Irig. 8. Dumtar: Response to Legitimacy Gaps.

\section{'Type's of Strategie's}

MarMillan Bloedel (Table 3 and Fig. 9). Substantive, concrete strategies are gencrally more desirable to the relevant publics, while companies tend to favor more cost-clfective symbolic assurances. For MB, over the period of the study, the mix between these two categories of strategies was almost reversed, from $33 \%$ substantive in 1991 to $63 \%$ in 1995 , and $67 \%$ symbolic in 1991 to $37 \%$ in 199.5. There was a shift toward more socially desirable strategies, indicating aclual changes in corporate hehavior. This pattern fits into the legitimacy theory framework, with societal pressure resulting in concrete action. as the company changed to conform to societal demands and expectations. This indicates a general trend toward becoming more isomorphic over time.

In the substantive category, $\mathrm{MB}$ used role performance 144 times and coerche isomorphism once. The use of the role performance strategy showed an impressive increase in 1993, compared with 1991 and 1992. This coincided with the barrage of adverse media reports that $\mathrm{MB}$ and the industry were subjecled to in 1993. Isomorphism was again evident in the increase from 38 substantive responses in 1993 to 55 in 1995. MB did nol attempl to reporl on the use of the most difficult strategy of all, namely, that of trying to alter socially institutionalized practices. 
Table 3. Legitimation Strategies in Annual Reports

\begin{tabular}{|c|c|c|c|c|c|c|c|c|c|c|c|c|}
\hline \multirow[b]{2}{*}{ Strategies: } & \multicolumn{7}{|c|}{ MacMillan Bloedel } & \multicolumn{5}{|c|}{ Domtar } \\
\hline & 1991 & 1992 & 1993 & 1994 & 1995 & Total & 1991 & 1992 & 1993 & 1994 & 1995 & Totil \\
\hline Role performance & 7 & 7 & .38 & 37 & 55 & $1+4$ & 11 & 22 & 18 & 26 & 22 & 99 \\
\hline Coercive isomorphism & 0 & 0 & 0 & 1 & 0 & 1 & 0 & 1 & 1 & 0 & 0 & 2 \\
\hline Alter socially institutionalized practices & 0 & ) & 0 & 0 & 0 & 0 & 0 & () & 1 & 0 & () & 1 \\
\hline Total: Substantive & 7 & 7 & 38 & .38 & 55 & 145 & 11 & 2.3 & 20 & 26 & 22 & 102 \\
\hline Fspouse socially acceptable goals & 3 & 5 & 19 & 8 & 10 & 45 & 1 & 2 & 3 & 4 & 6 & 16 \\
\hline Deny and conceal & () & () & + & 0 & () & 4 & 0 & 0 & 0 & () & 0 & 0 \\
\hline Identify with symbols. values, insututions & 2 & 2 & 2 & 2 & 1 & $y$ & 0 & 1) & 0 & 0 & 0 & () \\
\hline Offer accounts & 5 & 3 & 6 & 7 & 5 & 26 & 11 & 2 & । & () & () & 3 \\
\hline Admission of guilt & 0 & 0 & 3 & 13 & 10 & 26 & 0 & 0 & ) & 0 & 0 & $\theta$ \\
\hline Offer apologics & 0 & 0 & 0 & 0 & 0 & 0 & 0 & 0 & () & 0 & 0 & () \\
\hline Ceremonial conformity & 0 & 2 & 4 & 1 & 1 & 8 & 0 & () & () & 1 & () & 1 \\
\hline Misrepresent or open to misinterpretation & 1 & 0 & 1 & 4 & 0 & 6 & 0 & () & () & (1) & () & (1) \\
\hline Avoid, trivialize, skirt the issue & 3 & 0 & + & 4 & 5 & 16 & 0 & 0 & () & () & () & 0 \\
\hline Total: Symbolic & $1+$ & 12 & 43 & 39 & 32 & 140 & 1 & 4 & 4 & 5 & 6 & 20) \\
\hline Total: Subtantive and Symbolic & 21 & 19 & 81 & $7 ?$ & 87 & $2 \times 5$ & 32 & 27 & 24 & 31 & 28 & 122 \\
\hline
\end{tabular}




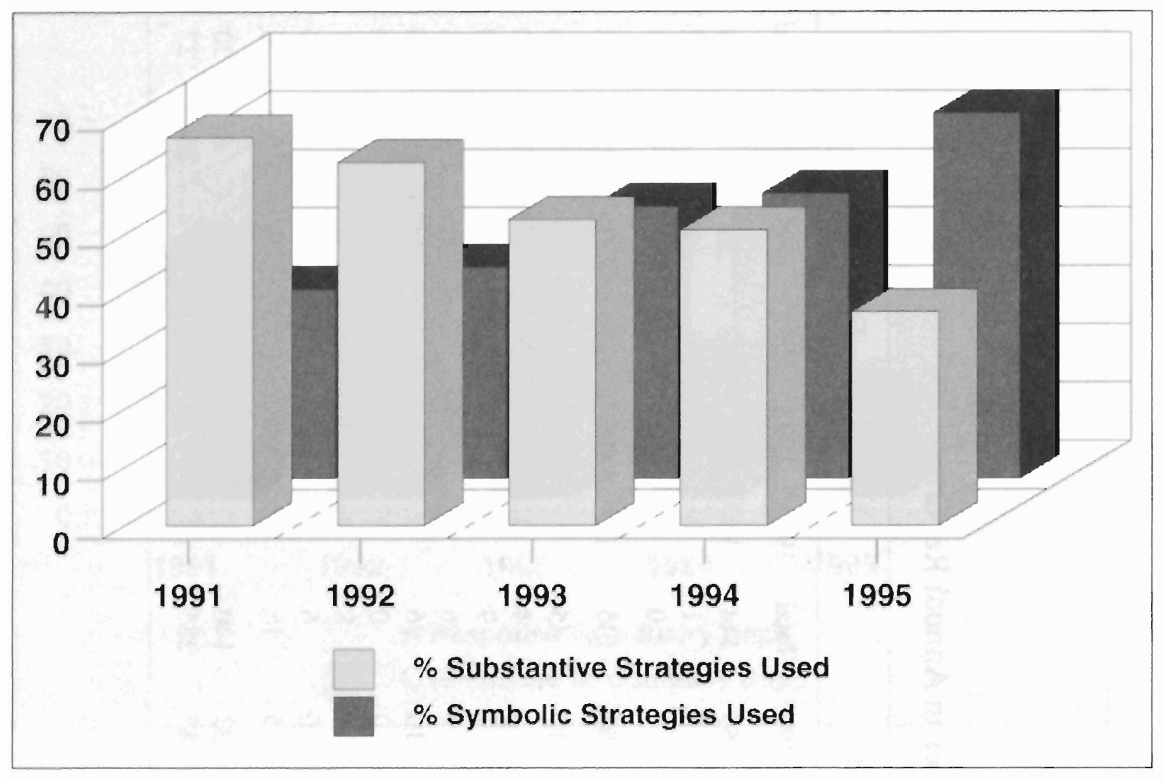

Fig. 9. MB: Mix of Strategies.

MB used eight out of a possible nine symbolic strategies. The most widely used symbolic strategy was that of espousing socially acceptable goals. Overall, it was used 45 times out of a total symbolic strategy usage of 140. Its use was particularly pronounced in 1993, the year in which adverse companyrelated news media reports peaked and MB's quantity of environmental disclosure surged in defense of its legitimacy. The other two symbolic strategies that enjoyed considerable usage, were offering accounts and admission of guilt. Each was used 26 times. The admission of guilt strategy started modestly in 1993, and then made its presence felt in 1994 and 1995, as MB became more attuned to societal expectations. The offering of apologies was the one symbolic strategy that was not in MB's arsenal. From an accounting perspective, the most disturbing strategy was misrepresentation (for the worst example, see Appendix C).

Domtar (Table 3 and Fig. 10). For Domtar, the mix between strategies changed, from $92 \%$ substantive in 1991 to $79 \%$ in 1995 , and $8 \%$ symbolic in 1991 to $21 \%$ in 1995 . This fits the legitimacy theory framework, with societal pressure in 1991 resulting in more concrete action, as the company changed to conform to environmental demands and expectations. As the company itself 


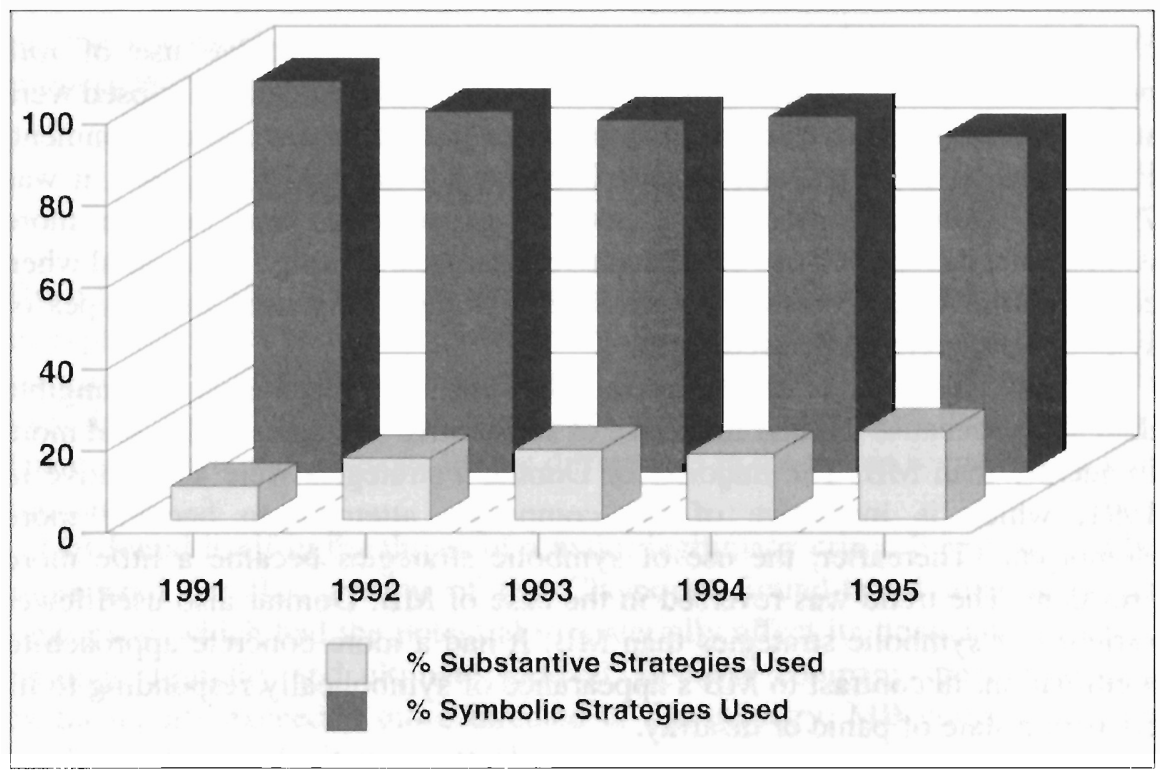

Fig. 10. Domtar: Mix of Strategies.

was targeted less and less, so the mix of strategies shifted to provide more symbolic assurances. However, the predominant use of substantive strallegies over this extended period indicates attempts at becoming isomorphic with its societal environment. Domtar used role performance 99 times, coercive isomorphism twice and altering socially institutionalized practices once. Domtar made sparing use of symbolic strategies. using only three types out of a possible nine over the five-year period. The most frequently used symbolic strategy was espousing socially acceptable goals. It was used 16 times out of a total symbolic strategy usage of 20 . The other symbolic strategies used were offering accounts (three times) and ceremonial conformity (once).

Cross-case comparison. MB, caught unawares in the throes of a legitimacy crisis, used a wide variety of symbolic strategies. Iividenced by the use of all but one of the symbolic strategies, including misrepresentation, societal demands forced MB into portraying a higher degree of isomorphism. This was confirmed by the increased propensity toward disclosing substantive strategies, which replaced the symbolic, over the five-year period. This is also consistent with Laughlin's (1991) writings. The bigger the exogenous shock, the greater the possibility of a change to an organization's core philosophies, which in turn leads to substantive change. 
In contrast, Domtar's reactions are reflected by extensive use of role performance from 1991 onwards. In 1991, 92\% of the strategies disclosed were substantive, exhibiting changes in its behavior toward the natural environment. From 1992 to 1994, this declined to between $83 \%$ and $85 \%$. In 1995, it was $79 \%$. As Domtar conformed to societal expectations and became more isomorphic, its reported use of substantive strategies, although substantial when compared to $\mathrm{MB}$, decreased progressively. Domtar only used three types of symbolic strategies. MB used eight.

Domtar's reactions to societal demands were more responsive and tangible than MB's, because Domtar made use of substantive strategies earlier and more frequently than MB. The majority of Domtar's strategies were substantive in 1991, which is indicative of the company's attempts to become more isomorphic. Thereafter, the use of symbolic strategies became a little more prevalent. The trend was reversed in the case of MB. Domtar also used fewer varieties of symbolic strategies than $\mathrm{MB}$. It had a more concrete approach to legitimation, in contrast to MB's appearance of symbolically responding to its crisis in a state of panic or disarray.

\section{LIMITATIONS}

Several limitations warrant mention. First, the study is limited to voluntary environmental disclosure in annual reports. Mandatory disclosure is excluded, because it falls outside the scope of the research question. Second, the authors recognize that CSD can be made via communication media other than the annual report (e.g. filings with security commissions, company newsletters, press releases, paid news media advertising, and brochures). From an accounting perspective, an explanation is specifically being sought for voluntary environmental disclosure in annual reports. Therefore, this study is limited to annual reports. Third, this study is limited to recorded Canadian norms and values. It was not possible to control for the effects of the societal norms and values of major export clients and international business associates of the corporations under investigation. Fourth, conclusions could not be drawn about the use of the concealment legitimation strategy. If use of the concealment strategy involved non-disclosure, it would not have been detected, as the legitimacy gaps and news reports to which the companies did not voluntarily respond could have been dealt with via mandatory disclosure or an

alternative communication medium. Fifth, this study was not designed to detect specific instances of mimicry of the environmental disclosure of other organizations. Any of the items of disclosure could have resulted from mimicry, 
but the results show that adverse media reports would have preceded any mimicry that may have occurred.

\section{CONCLUSION AND RESEARCH DIRECTIONS}

The purpose of this study was to examine the potential for legitimacy theory as an explanation for voluntary environmental disclosure in the annual reports of companies. The hypothesis was tested on two cases and cross-case conclusions were developed. For each case, the results were consistent with the hypothesis. There were two main reasons for the differences in the trends found for the two companies.

$M B$ found itself in the throes of a major legitimacy crisis. It appeared to be unprepared for the severity of the Clayoquot Sound-based attacks on its legitimacy, which had the potential to materially affect its financial condition, earnings, liquidity and ultimate survival. Because company-specific adverse media reports exceeded those directed at the industry, MB concentrated on warding off direct legitimacy attacks.

Domtar's major problem was site contamination, resulting from the use of wood preservatives at its old plants. Although it experienced attacks from within the communities in which these plants were situated, future clean-up costs were not expected to have an adverse or material effect on Domtar's future financial condition, earnings or liquidity. A far greater threat to Domtar was an industry-related problem, the call for an international boycott of Canadian forest products. Industry-related adverse media reports exceeded company-specific reports. Consequently, Domtar put more effort into responding to industry-related legitimacy issues.

The second reason for the difference in trends was that Domtar's main legitimacy problem, site contamination, was subject to mandatory disclosure requirements. The findings provide the following directions for future research:

To provide quantitative empirical support for legitimacy theory as an explanation for environmental disclosure, researchers could test whether the quantity (measured by number of pages of disclosure) and quality (measured by substantive as opposed to symbolic strategies) of disclosure are positively related to the magnitude (measured by number of adverse media reports) of a company's legitimacy gaps.

Use the hypothesis and research design in this study to investigate an organization that is perceived to be a 'green' market leader in its industry with regard to environmental disclosure. 
Other suggestions for future research, which have a broader focus and integrate legitimacy with other social theories are (1) the incorporation of classical political economy theory perspectives and stakeholder theory into the suggested framework, as suggested by Gray et al. (1995a), and (2) the use of structuration theory, of which legitimation is an integral part, to examine the management process behind the initiation of environmental disclosure (see Buhr, 1997). A particularly interesting case for this would be MacMillan Bloedel.

A final suggestion for future research is to use a multi-case research design to investigate other issues of concern to society, for example, an examination of the annual report disclosure of the gun and entertainment industries in reaction to the recent school shootings in America.

This research resulted in three important contributions. First, news media reports were used as a measure of organizational legitimacy. Second, three additional legitimation strategies were identified. Third, a research design was presented that provides a structure for the identification of particular types of legitimation strategies used by companies in their annual reports. Yin's (1989) well-established case study research design was used in an innovative manner, thereby paving the way for replication by other accounting researchers.

\section{NOTES}

1. This paper stems from the lead author's doctoral dissertation at the University of Pon Elizabeth. Prior versions were presented at the 1999 American Accounting Association Midwest Regional and National Meetings.

2. Equivalent to Habermasian accounting scholar Laughlin's (1991) morphogenetic change.

3. Equivalent to Laughlin's (1991) morphostatic change.

4. Those involving extensive public participation, such as the Green Plan, Sustainable Forests: A Canadian Commitment, Partners in Sustainable Development of Forests, and the Forest Practices Code of British Columbia.

\section{REFERENCES}

Adams, R. (1992). Green reporting and the consumer movement. In: D. Owen (Ed.), Green reporting: Actomtancy and the Challenge of the Nineties (pp. 106-118). London: Chapman Hall.

Amold. P. J. (1990). The state and political theory in corporate social disclosure research: A response 10 Guthrie and Parker. Advances in Public Interest Accounting, 3, 177-181

Ashlorth, B. E., \& Gibbs, B. W. (1990). The double-edge of organizational legitimation. Organization Science. I(2), 177-194.

Bryman, A. (1988). Quantity and quality in social research. London: Unwin Hyman. 
Buhr, N. (1994). Environmental disclosure: An empirical study of corporate communication in Canada and the role of accounting. Unpublisted PhD dissertation. University of Westem Ontario: London.

Buhr, N. (1997). Looking behind the curtain: A structuration view of the intiation of emironmental reports. Conference Procedings, Fifth Interdisciplinary Perspectives on Accounting Conference (July 7-9), Manchester, United Kingdom.

Buhr, N. (1998). Environmental performance, legislation and annual report disclosure: The case of acid rain and Falconbridge. Accounting, Auditing \& Accommability Joumal, $1 /(2)$, 163-190.

Buhr. N., \& Freedman. M. (n.d./1996). A comparison of mandated and voluntary envirommental disclosure: The case of Canada and the United States. School of Management, Binghamton University. New York. [WWW document|. URL hup://es.man.ac.uk/cpa96/ txt/buhr.txt

Canadian Business and Current Affairs. (1996). [Database]. Palo Alo, CA: Dialog Information Services (Distributor).

Colbert. G. J., \& Spicer, B. H. (1995). A multi-case investigation of a theory of the transfer pricing process. Accotming, Organizations and Society, 20(6), 423-456.

Deegan, C., \& Gordon, B. (1996). A study of the environmental disclosure policies of Australian corporations. Accounting and Business Research, 26(3), 187-199.

Deegan, C., \& Rankin. M. (1996). Do Australian companies report environmental new's objectively? An analysis of envirommental disclosures by firms prosecuted successfully by the Environmental Protection Authority. Accounting, Auditing \& Accoumability dournul, $9(2), 50-67$.

Deegan, C. \& Rankin, M. (1997). The materiality of envirommental information to users of anmual reports. Accounting, Auditing \& Accommobility Joumal, 10(4), 562-583.

DiMaggio, P. J., \& Powell, W. W. (1983). The iron cage revisited: Institutional isomorphism and collective rationality in organizational fields. American Sociological Revien: 4\$, 147-160.

Dowling. J., \& Preffer, J. (1975). Organizational legitimacy: Social values and organizational behavior. Pacific Sociological Review, 18(1), 122-138.

Fekrat, M. A., Inclan, C., \& Petroni, D. (1996). Corporate environmental disclosures: Competitive disclosure hypothesis using 1991 annual report data. Intemational Joumal of Accounting, $3 /(2), 175-195$.

Flinn, J. (1995). Investors give annual reports high marks. The Glohe and Mail (September 6), B20.

Foot, R. (1996). New government report bolsters move to ban Maine clear cuts. Telegraph Journal (May 13), A I-A2.

Freedman, M., \& Jaggi, B. (1988). An analysis of the association between pollution disclosure and economic performance. Accounting. Audiling \& Accountability Journal, I(2), 43-58.

Gordon, S. (1997). Outlook 97. CA Magazine (January/February): 19-23.

Gray, R. H. (1993). Current practice in environmental reporting. Social and Environmental Accounting, 13(1), 6-9.

Gray, R. H. (1994). The developing state-of-the-art in emvironmental reporting in the U.K. and continental Europe. Discussion paper, Centre for Social and Environmental Accounting Research, University of Dundee.

Gray, R. H., Bebbington, J., \& Walters, D. (1993). Accounting for the environment. London: Paul Chapman. 
Gray, R. H., Kouhy, R., \& Lavers, S. (1995a). Corporate social and environmental reporting: A review of the literature and a longitudinal study of U.K. disclosure. Accounting, Alsdiring \& Accountability Journal, 8(2), 47-77.

Gray, R. H., Kouhy, R., \& Lavers, S. (1995b). Methodological themes: Constructing a research database of social and environmental reporting by U.K. companies. Accounting, Alsdining \& Accounability Joumal, 8(2), 78-101.

Gray, R. H., Owen, D. L., \& Maunders, K. T. (1987). Corporate social reporting: Accounting and accountability. London: Prentice-Hall.

Gray, R. H., Owen, D. L., \& Maunders, K. T. (1988). Corporate social reporting: Emerging trends in accountability and the social contract. Accounting, Auditing \& Accoumability Joumal, I(1), 6-20.

Guthrie, J., \& Parker, L. D. (1989). Corporate social reporting: A rebuttal of legitimacy theory. Accounting and Business Research, 19(76), 343-352.

Guthrie, J., \& Parker, L. D. (1990). Corporate social disclosure practice: A comparative international analysis. Advances in Public Interest Accounting, 3, 159-175.

Hogner, R. H. (1982). Corporate social reporting: Eight decades of development at U. S. Steel. Research in Corporate Social Performance and Policy, 4, 243-250.

Laughlin, R. (1991). Environmental disturbances and organizational transitions and transformations: Some alternative models. Ojganization studies, 12(2), 209-232.

Maclsaac, R., \& Champagne, A. (1994). Clayoquot mass rials: Defending the rainforest. Philadelphia, PA: New Society Publishers.

Mathews, M. R. (1993). Socially responsible accounting. London: Chapman \& Hall.

Mathews, M. R. (1998). Accounting to a Wider Society: Towards a mega-accounting theury: Forum Paper at the Annual Meeting of the American Accounting Association, New Orleans.

Meyer, I. W., \& Rowan, B. (1977). Institutionalized organizations: Formal structure as myth and ceremony. American Journal of Sociology, 83(2), 340-363.

Miles. M. B. (1979). Qualitative data as an attractive nuisance: The problem of analysis. Administrative Science Quarterly, 24, 590-601.

Neu, D. Warsame, H., \& Pedwell, K. (1998). Managing Public Impressions: Environmental Disclosures in Annual Reports. Accounting, Organizations and Society 23(3), 265-282.

Niskala, M., \& Pretes, M. (1995). Environmental reporting in Finland: A note on the use of annual reports. Accounting, Organizations and Societ): 20(6), 457-466.

Orion. D. (1991). Pulp mills: Know your enemy. Canadian Dimension (March), 31-33.

Patten. D. M. (1991). Exposure. legitimacy, and social disclosure. Journal of Accounting and Public Policy 10, 297-308.

Patten, D. M. (1992). Intra-industry environmental disclosures in response to the Alaskan oil spill: A note on legitimacy theory. Accounting. Organizations and Society. 17(5), 471-475.

Pleffer, J. (1981). Management as symbolic action: The creation and maintenance of organizational paradigms. Research in Orgamizational Behavior 3, 1-52.

Preston, L. E. (1975). Corporation and society: The search for a paradigm. Journal of Economic Literature (July), 434-453.

Puxty, A. G. (1986). Social accounting as immanent legitimation: A critique of a technicist ideology. Advances in Public Interest Accounting. 1, 95-111.

Richardson, A. J. (1987). Accounting as a legitimating institution. Accounting, Organizations and Seciety, 12(4), 341-355.

Robertson, D. C.. \& Nicholson, N. (1996). Expressions of corporate social responsibility in U.K. firms. Jounal of Business Ethics, 1095-1106. 
Rusk, J. (1992). Minor forestry issues resolved. Globe \& Mail (June 6), A4.

Savage, A. (1998). Environmental disclosure in annual reports: A legirimacy theory framework. Paper presented at the Annual Meeting of the American Accounting Association, New Orleans.

Sherbanowski, J. (1991). Recycling an industry. Canadian Banker (July/August), 98, 48-52.

Silverman, D. (1993). Interpreting qualitative data: Methods for analysing talk, text and interaction. London: Sage.

Suchman, M. C. (1995). Managing legitimacy: Strategic and institutional approaches. Acadeny of Management Review, 20(3), 571-610.

Tinker, A. M., \& Lowe, E. A. (1980). A rationale for corporate social reporting and evidence from organizational research. Journal of Business Finance and Accouming, 7(1), 1-15.

Ullmann, A. A. (1985). Data in search of a theory: A critical examination of the relationships among social performance, social disclosure, and economic performance of $U$. S. firms. Academy of Management Review, 10(3), 540-557.

United Nations. (1994). Company environmental reporting. New York: United Nations.

United Nations Economic and Social Council. (1992). Environmental disclosures: International survey of corporate reporting practices, (January 30): New York: United Nations.

Wiseman, J. (1982). An evaluation of environmental disclosures made in corporate annual reports. Accounting, Organizations and Society, 7(1), 53-63.

Yin, R. K. (1989). Case study research: Design and methods (rev. ed.). Newbury Park, CA: Sage.

Zenisek, T. J. (1979). Corporate social responsibility: A conceptualization based on organizationat literature. Academy of Management Review, 4(3), 359-368.

\section{APPENDIX A. CATEGORIES OF ENVIRONMENTAL DISCLOSURE}

(1) Environmental Policy

(2) Environmental Management System (EMS)

(3) Risk Management - General (specifics under spills, emissions, effluents, land contamination)

(4) Environmental Auditing

(5) Goals and Targets

(6) Legal Compliance - Court-related or General (specifics under spills, emissions, effluents, land contamination)

(7) Other Management and System Disclosure

(8) Land Contamination and Remediation

(9) Habitats

(10) Wastes

(11) Air Emissions

(12) Water Effluents

(13) Spills

(14) Noise and Odours (other than where odours relate to categories 11 or 12) 

(15) Product Stewardship
(16) Environmental Spending
(17) Environmental Cost Accounting
(18) Sustainable Development Reporting

Sources: Buhr \& Freedman (1996); United Nations (1994).

\section{APPENDIX B. GUIDELINES FOR CODING}

\section{The Context of the Coding}

Three decision rules will be used (Buhr, 1994, 346):

(1) Everything in the environmental report will be considered environmental disclosure other than the following: Information about the company, nonenvironmental community interaction, and health and safety matters not directly related to the environmental actions of the company.

(2) For special sections in annual reports that are clearly devoted to environmental reporting, everything will be considered environmental disclosure other than: Information about the company, non-environmental community interaction, and health and safety matters not directly related to the environmental actions of the company.

(3) Where the above two decision rules are irrelevant, the unit of context wil] be the section heading, subsection heading, paragraph or sentence. whichever is the most applicable.

\section{Information to be Coded}

All text will be coded. This includes headings, graphs, explanatory illustrations (without which the impact of the accompanying text would be lost), and captions for photographs, but not the photographs themselves. Information types that will be excluded from coding are: Tables of contents, glossaries, corporate directories, references to other available publications, user response cards enclosed with or attached to reports, and information regarding the production of the report, a common example being along the lines of "This report was printed on recycled paper" (Buhr, 1994, 347-348).

\section{Procedures for Recording Information on Worksheet}

This section sets out the procedures for the actual coding process, the results of which must be recorded on the worksheet (not reproduced here, but available 
upon request). A separate worksheet will be completed for each of the 199] to 1995 financial years for each company. The procedures are as follows:

(1) Environmental disclosure in the annual report, and in any other publication referred to in the annual report, will be identified, by taking cognizance of the three decision rules, the key terms identified by Buhr (1994, 323-334), and the categories and subcategories identified in Appendix A. This disclosure will be broken down into the various categories identified on the worksheet (to distinguish between voluntary and mandatory disclosure and to provide a framework for the data analysis), and the location of the information will be specified in the column provided for this purpose.

(2) Quantity of disclosure, reflected in proportions of pages of a standard letter-sized page (to the nearest $1 \%$ of a page) will be shown per subcategory. These measurements will be taken by using a transparent grid with standard one inch margins all round, along the lines of the Gray et al. study $(1995 \mathrm{~b}, 84)$. Each block of the grid represents $1 \%$ of a page of text. These measurements will then be aggregated to obtain a total number of pages of disclosure per year for each company.

\section{APPENDIX C: EXAMPLES OF LEGITIMACY GAPS AND CORRESPONDING LEGITIMATION STRATEGIES}

Legitimation strategies are shown in (italics).

The year and number of media reports giving rise to each gap are shown in [brackets].

\section{Example 1}

MB's 1993 environmental report (p. 1) states its desire to be accountable, worthy of the public trust, a leader in the forest community, and says that it welcomes eco-labeling (espousing socially acceptable goals). $\mathrm{MB}$ also disclosed details of actual modifications to mill processes and the installation of new effluent treatment systems, to comply with new regulations and standards (role performance).

This was in response to the following legitimacy gaps:

MB's public image is deteriorating because of its lack of concern for the environment $[1991-3 ; 1992-2 ; 1993-10]$; it has a large number of criminal convictions [1993-2] and charges pending [1993-1] for environmental offences; it engages in forestry practices contrary to the public interest [1993-5] and is guilty of mismanaging British Columbian (BC) forests under its control [1993-5]; its Port Alberni and Powell River pulp mills are the worst 
polluters in BC [1992-2]; pulp mill effluent is polluting Canadian waters [1991-6; 1992-3], discharging highly toxic waste, including dioxins and furans [1991-2], and exceeding levels permitted by government guidelines and/or regulations [1991-2;1992-5]; MB is unwilling to change its environmentally unfriendly processes and practices $[1991-4 ; 1992-2 ; 1993-8]$, resulting in the destruction of forest ecosystems [1991-2; 1992-1; 1993-2]; markets are demanding eco-labeling of forestry products [1993-3].

\section{Example 2}

MB's 1994 annual environmental report (p.4) specified that it had been convicted of only 15 environmental offences in 25 years (misrepresentation), but all violations were unintentional and the result of equipment breakdown or human error (offering accounts). In response, Greenpeace alleged, via media reports, that there had been at least 86 environmental violations. In two subsequent newspaper reports (Vancouver Sun, April 12, 1995, p. B2, 'MacBlo admits to 4 more convictions' and Globe \& Mail, April 13, 1995 p.B6, 'MacBlo acknowledges environmental convictions'), MB conceded that the 1994 annual environmental report was inaccurate.

This was in response to the following legitimacy gaps:

$\mathrm{MB}$ has a large number of criminal convictions for environmental offences [1993-2; 1994-3] and a large number of charges pending for illegal environmental activities [1993-1; 1994-1]; MB was the worst corporate offender in the BC forest industry [1994-1], violated government guidelines/ laws aimed at safeguarding salmon streams and, in some instances, lied by misclassifying salmon streams to avoid compliance [1993-2; 1994-5].

\section{Example 3}

MB's 1994 annual environmental report (p. 5) discloses a fine of $\$ 206,000$ (admission of guilt) for 'inadvertently' (offering an account) harvesting timber outside of approved cut block boundaries in Clayoquot Sound. It explains that the area was designated for potential logging, though final approval had not been granted (trivializing the issue). Steps to improve its boundary-marking lechnique have been taken to reduce the risk of a recurrence (role performance).

This was in response to the following legitimacy gaps:

MB illegally logged trees in the Clayoquot Sound rainforest or other parts of Vancouver Island [1992-1; 1993-2; 1994-4] and was fined the largest amount in BC history and the maximum penalty under the Forest Act [1994-2]. 


\section{Example 4}

MB's 1992 annual report (p. 25) cited an example of how the company's environmental actions surpassed formal regulatory requirements. It reported that higher than usual summer water temperatures near its Alberni mill interfered with salmon movement and spawning. $\mathrm{MB}$, together with government fisheries and BC Hydro, moved cold water into the river, assisting the salmon in completing their journey upstream (ceremonial conformity).

This was in response to the following legitimacy gaps:

Excessive effluent discharges from the Alberni pulp mill are poisoning or causing stress to fish [1991-3; 1992-4]; 100,000 sockeye salmon had died in the oxygen-depleted Alberni Inlet in 1990 (1991-1; 1992-1); there has been a progressive deterioration in water quality since the Alberni pulp mill has been in operation $(1991-1)$. 